\title{
Global Shocks and the Growth Constraints in the Malaysian Economy 1970-2012
}

\author{
Marwan Abdl-Malik Thanoon \\ Faculty of Economics and Management, Mosul University, Iraq
}

\begin{abstract}
A structural dynamic model is developed to assess Malaysia's external and internal constraints prior to the East Asian crisis. The model computes the resource requirement to move the economy to a more sustainable form of development. In addition, we examine how the 2008 global financial crisis affected economic performance. The calibrated results clearly show the trade-off between the rate of investment and economic growth under the fiscal and foreign exchange constraints. Our results also highlight the importance of the external trade and FDI to achieve a modest growth.
\end{abstract}

KEYWORDS : Three-Gap Model, Malaysia, Asian Crisis.

\section{INTRODUCTION}

Malaysia intends to transform its economy through an industrialisation development plan to become a fully developed country by the year 2020. To achieve these objectives, it is necessary for policymakers to fully understand the nature, magnitude, and the evolution of major resource constraints that can influence the outcome of policy actions. Understanding these constraints provides policymakers with a set of policy options that can be used to achieve the national agenda. For this task, we construct a three-gap model that focuses on the major imbalances of the economy ${ }^{1}$. Our focus are on both domestic and external factors that govern the economic outcomes of empirical results. The 1997 Asian financial crisis and its effects on the neighbouring economies demonstrated that the growth performance of the East Asian countries (namely, Malaysia, Thailand, Republic of South Korea, Indonesia, and the Philippines) was severely affected by foreign capital reversal in the aftermath of the crisis. It is wellknown that the reduction of Japanese direct investments inflows into these countries was a major factor that forced them to pursue short-term capital debts to cover their growing trade deficits; thereby setting the stage for financial crises that triggered the region's economic

Academic Journal of Nawroz University

(AJNU) Volume 7, No 3 (2018).

Received 10 April 2018;

Regular research paper : Published 20 July 2018

Corresponding author's e-mail : marthano2001@yahoo.com

Copyright (2018 Marwan Abdl-Malik Thanoon.

This is an open access article distributed under the

Creative Commons Attribution License. recession (Whitt, 1999; Hart-Landsberg, 1998). East Asia has felt the full brunt of the global financial crisis because of its close trade and financial links with highincome countries, and because of declining investment, foreign capital (foreign direct investment and portfolio investment), as well as a drop in exports. The interaction of Malaysia's development strategy with negative exogenous shocks associated with trade, foreign direct investment (FDI), and debt flows that contributed to the crisis has not been fully explained (Kawai \& Takagi, 2008; Giselle, 2007). Therefore, we intend to: (1) identify the major resource constraints that negatively affect economic growth; (2) investigate the domestic and foreign resources situations before and during the different crisis periods; (3) analyse how the 2008 global crisis has affected macroeconomic performances; and (4) provide policy options by narrowing the resource gap so as to push the economy on a more sustainable growth path. We aim to identify the major constraints as well as the initiatives that need to be addressed by the policymakers to reduce the resource gap to a level that existed prior to the crisis. The two crises have had significant impact on the economy. To provide answers to these questions, a simple growth model constraine by domestic savings, foreign exchange, and public sector resources is formulated and estimated (For a more detailed discussion of the model, please looked to the article by Thanoon \& Baharumshah (2003), and Thanoon et al. (2006). The rest of this paper is organized as follows. Section 2 provides an overview of the economy, mainly for the period from 1970-2008. Section 3 presents the empirical results are discussed of the simulation exercise based on the three-gap analysis. The expected 
effect of the recent global crisis was analysed in Section 4 . The paper ends with concluding remarks and draws some policy implications in section 5 .

\section{Performance of the Malaysian Economy: Before and} After the Fall

In 1986, Malaysia defied an external shock engendered by the vulnerability of export commodity prices in mid1980s. Policymakers reacted to this shock by adopting a new economic policy aimed at promoting macroeconomic stability, initiating a more liberal set of guidelines for foreign equity participation, and reducing government expenditures. These reforms allowed the economy to achieve a real gross domestic product (GDP) growth of about $8.5 \%$ between 1991 and 1997. Per capita income increase two-fold by 1997 in terms of the US dollar and the incidence of poverty declined sharply from a high of $16.5 \%$ to $5.1 \%$ (Economic Report, 2004). The economy, however, recorded a large and persistent current account deficit in the late 1980s and for most of the 1990s, prior to the currency crisis (Evan \& Baharumshah, 2006). The external deficit amounted to Ringgit Malaysia (RM) 21.6 billion (10.4\% of GNP) in 1995, but declined to RM12.2 billion in 1996 and RM14.2 billion in 1997 (5.4\% of GNP). Nonetheless, this was considered high compared to the other ASEAN member countries that were severely affected by the crisis, including Thailand. (Asian Development Bank, 2015) The data show that both gross domestic savings (GDS) and gross domestic investment (GDI), have increased significantly over the past few decades. The share of saving to GDP rose from $26 \%$ in the 1970 s to $43 \%$ in 1996 , before the onset of the Asian financial crisis. GDI increased from 14\% to $44.5 \%$ during the same period. In mid-1997, however, the performance of the economy was adversely affected by the deflationary impact of the financial crisis that took the region by surprise. In 1998, real GDP growth declined by $4.8 \%$ present. From 1998 to 2007, the average annual real GDP growth rate was estimated at $3.8 \%$, much lower than the rates prior to the crisis. The slow growth was associated with lower domestic investments. In 1998, the private investment rate started to decline sharply in the aftermath of the crisis. The reduction in private investment resulted in a downward trend for the total investment rate. Since then, capital formation has been mainly supported by public investment, but it is not clear whether this will be sustainable in the long-run. Both GDS and GDI have declined during the post-crisis period (1998-2007), but the GDI decline has been more substantial. GDS decreased to an average $40 \%$, and GDI decreased to $22 \%$. During the same period, we observed that savings from the public sector plunged in to $22 \%$, while the share of private saving declined to $28.2 \%$.
Meanwhile, FDI contracted to RM 7.1 billion by the end of 1998 and declined sharply to RM 27 million (US\$ 6 million) in 2007 and was negative -RM 8813 billion (US\$ 2562 million) in 2008, mainly due to uncertainties arising from volatile exchange rates and shift the FDI to new profitable countries like China, Vietnam, and other Asian countries. The ringgit (RM) continued to fluctuate against the US dollar, although it weakened for a while during 2007, it appreciate 5.8\% against the dollar, and $13.8 \%$ since the Malaysia ended the peg against the US dollar in mid 2005 (Economic Report, 2015). When examining debt, the data reveal that total debt increased from US\$ 48.3 billion in 2003 to US\$ 52.5 billion in 2008 . Public debt rose from $35 \%$ of GDP in 2000 to a peak of $46 \%$ in 2005 , before trending down to about $40 \%$ in 2008. The overall financial position of the government recorded a deficit during the 1998-2007 period-- RM 22.7 billion deficits in 2007 that accounted for approximately $4 \%$ of total GDP. The deficit was primarily due to fiscal stimulus measures, increased government spending, and lower tax revenue collection, which declined by $13.6 \%$ to RM 55 million in 2007 (1997: RM 70.2 million). The overall financial account posted a deficit US\$ 10.8 billion, and the trade balance reduced from RM 108.2 in 2005 to RM 100.4 Billion in 2007 (Key Indicators, 2013).

\section{The Three-Gap Model}

Bacha (1990), Iqbal et al. (2000), Thanoon et al. (2006), among others used the three-gap model to estimate the resource requirements for the developing countries. A brief description of the model used in this study is as follows: Equation 1 hypothesises that private investment $\left(i_{p}\right)$ is a linear function of the level of government investment $\left(i_{g}\right)$ through the parameter $\alpha$ and through an accelerator term, $\beta$. The private investment and government investment are assumed to be complementary, implying that government investment in infrastructure and public utility are likely to crowd in investment in the private sector. The parameters $(\alpha$ and $\beta$ ) in equation 1 indicate how effectively public sector $\left(i_{g}\right)$ can stimulate the capacity expansion $U$. Low values for $\alpha$ and $\beta$ mean that larger foreign exchange transfers, more vigorous tax efforts or a larger $\pi$ is required for public investment to support a given increase in the rate of capacity growth (say, one percent). Equation 2 is the total investment demand (i), derived after substituting equation 1 into 9. Equation 3 suggests that private sector savings $\left(S_{p}\right)$ are a linear function of the activity variable. The parameter $\sigma_{0}$ implicitly includes private foreign interest payment. The observed value of $\sigma_{0}$ may also shift over time in response to capital flight. The marginal saving rate $\sigma_{1}$ implicitly includes the effects of transfers and taxes, and we assume here that private saving increases with the 
rate of capacity utilisation as measured by the $\sigma_{1}$ coefficient. The fiscal effort variable $(Z)$ of government revenues is hypothesised as the linear function of the level of economic activity (equation 4 ). Typically, $Z_{1}$ is expected to be greater than zero as tax revenues and public enterprise profits rise with the level of economic activity. Equation 5 postulates that the level of intermediate inputs $M_{r}$ is a linear function of the activity variable $U$. Equation 6 maintains that only a fraction of the level of investment (i) is imported, while the rest is sourced domestically. The import share (1- $\theta)$ in some circumstances may be elastic to investment itself: (1- $\theta) i=V_{0}+V_{1} \times i$ is typically adopted in several studies. Equation 7 in Table 1 states that the level of exports $(X)$ is a linear function of the activity variable. Export sales seem to be cut back as producers turn to the domestic market when domestic activity $(U)$ rises. Equation 8 expresses the growth rate of potential output $(g)$ as a linear function of investment normalised by the level of potential output $i$, the parameter $\kappa$ denotes the incremental capital-output ratio, and the parameter $g_{0}$ represents both the influence of depreciation of capital assets in the economy and underlying growth prospects of the economy under investigation. Finally, to close-up the system, we used six identities (Equations 9-14). To sum up, the model employed in our study comprises 22 variables and 15 parameters, and is bounded by 8 behaviour equations and 6 identities. The growth version of the model appears as equations (1-3) and the government investment behaviour appears as equations (4-6). Equation (7) in Table 1 relates public sector investment $\left(i_{g}\right)$ to capacity utilisation $(U)$, and a targeted growth rate $(g)$. [Insert Table 1]

\section{Empirical Results and Discussion \\ The Pre-Crisis Period}

Figure (Fig.) 1 and Table 2 illustrate the calibration results from the three-gap model. As depicted in Fig. 1, both the fiscal and savings gaps are positively sloped, indicating that if capacity utilization rises, then the potential growth rate of output will also rise. However, the opposite is true for the foreign gap schedule. It is worth mentioning that the foreign gap is expected to shift downward at the onset of a financial crisis due to economic slow-down, and may shift back as foreign investors (multinational) regain their confidence about the future prospects of the economy and foreign capital begins to flow back into the economy. To further investigate the negative impacts of the 1997 crisis on the economy, we adopt a number of simulation exercises mainly to reflect the trend during the pre- and postcrisis eras. According to the results obtained from the model, the equilibrium position with respect to the year 1995 (before the crisis) is depicted in Fig. 1 as point A, where all three equations intersect with each other. At equilibrium, we estimated the capacity utilisation at
$87 \%$, and the economy was expected to grow at a modest rate of $5.5 \%$. Public investment stood at $8.5 \%$ of potential output. Clearly, Fig. 1 demonstrates the tradeoff between growth rate and capacity utilisation under the foreign exchange constraint, while either the savings or fiscal constraint has a positive slope. Interestingly, the results based on the analysis reveal that the fiscal gap equation is much steeper than the savings gap, and hence supporting the notion that the former was more binding than the latter during the pre-crisis period. It is worth noting that targeting for higher growth rates (e.g., more than 5.5\%) means more pressure on fiscal spending to finance higher desired investment levels ${ }^{2}$. Indeed, this outcome reflects the experiences of Malaysia and many of the crisis-affected East Asian countries prior to 1997. Thus, growth in 1995 was accompanied by insufficient foreign capital input; the available foreign finance would only be at point $\overline{\mathrm{A}}$, where the foreign exchange gap will be binding. Accordingly, the growth and capacity utilisation was lower at $4.5 \%$ of potential output and $83 \%$, respectively. This finding highlights the important connection between economic growth and foreign capital for the case of Malaysia in the late 1980s and 1990s. There is a need for foreign capital to supplement domestic resources in view of the mismatch between the capital requirement and the saving capacity. [Insert Table 2 and Figure 1]

\section{The Asian Financial Crisis Period 1997-2007}

What happened to the economy during the financial crisis? To answer this question, we examine the performance of the economy during the crisis period. On July 14, 1997, the ringgit (RM) was depreciate from RM 2.5/US dollar to 2.61, and then gradually fall to 2.83 on August 12 before reaching a low of RM 3.00 on September 2, 1997. Following poor domestic corporate performance and negative developments in Japan, the ringgit further weakened and reached a record low of RM 4.16 in July 1998. In 1998, the central bank (Bank Negara Malaysia) announced the fixing of the ringgit at 3.8/US dollar. The sharp fall in the exchange rate along with the stock market crash adversely affected businesses, undermined the domestic financial system, and naturally inflated the actual size of foreign debt. In what followed, the value of external debt exposure rose sharply. Therefore, as expected, the results from the three-gap analysis reveal that the burden of foreign debt had jumped from RM 99 billion in 1996 to RM 180 billion in 1998, and reach as high as 198 billion in 2007. Equally important, was the decline in the total investment, which fell by $50 \%$ during the crisis period from $42 \%$ of GDP in 1996 to $24 \%$ of GDP in 2002, and $20 \%$ in 2007 . The decline in investment was mainly due to uncertainties arising from exchange rate volatility, decline in both domestic and external demand for 
goods and services, high outflows of FDI, and lack of investor's confidence during a time of extreme economic instability coupled with a brief period of political instability. Our results shown (in Fig. 2.A) that the economy lost about $3 \%$ of its capacity utilization during the crisis period. The drop caused the economy to go into deep recession for several years between 1998 and 2007. The effect of the painful fiscal situation for the economy is that during the crisis period tax and non-tax revenues were bound to fall (which is also reflected in the fall in $Z_{0}$, and $Z_{1}$ ). The squeeze came from a decline in government revenue on the one hand, and higher budget expenditures on the other. The increase in expenditures was primarily due to the high cost of government debt payment that increased by 32\% during the crisis period and an increase in the rate of non-performing loans (NPLs) in the banking system estimated to have been $20 \%$. The fiscal constraint imposed restrictions (cutbacks) on government investment, and this led to the economic slow-down (3$5 \%$ ). Malaysian exports to the rest of the world, however, rose sharply until 2007. The currency devaluations ratified a swing of comparative advantage in the country's favour in the assembly industries for which production in the first wave of Asia's newly industrializing countries had become costly. The competitiveness had been enhanced after taking into account the combination of the currencies of Malaysia's trading partners, and correcting for inflation among the countries concerned. This meant that goods produced in Malaysia became relatively cheaper than those of the trading partners. We observed that Malaysia's exports increased by 45\% from RM 197 billion in 1996 to RM 286.5 billion in 1998, by $22 \%$ to RM 349.6 in 2002, and by $10.3 \%$ to RM 599 billon in 2006. For imports, Malaysian traders had to pay about $37 \%$ more to get the same pre1997 import volume (units). The imports grew by $0.2 \%$ in US dollar terms in 1998 and by nearly 11\% in 2006. All in all, this state affair suggests that the Malaysian trade had worsened compared to the pre-crisis period. Why was this so? The reason is simple: exporters had to sell more units to get the same amount of revenue they received during the pre-crisis period. Malaysian importers also had to pay more to get the same volume of pre-crisis imported goods. It is worth noting here that Malaysia's economic performance depends on the imports of intermediate and capital goods. As a result, the real GDP registered a negative growth rate in 1998, and grew slowly thereafter. By the end of 2008, exports grew by $2.1 \%$, while imports grew by $5 \%$, which is led to reduce in trade balance from RM 108,193 to RM 100,339 million. Using actual data from the crisis period (1997-2007), we derived the three-gap estimates. In 1998, the economy reached its lowest ebb due to currency depreciation, foreign debt accumulation, and political and economic instability. The GDP fell from $8.5 \%$ in 1996 to $-7.3 \%$ in 1998 (a negative growth for the first time since 1985). Notice that all three curves have shifted down (see Fig. 2.A). The recession in the late 2000s was clearly due to the big fall in foreign capital $(\Phi)$, and the large increase in foreign debt interest payments $\left(j^{\star}\right)$ and together with the subsequent increase in government deficit. Investment fell from $46 \%$ of GDP to $22 \%$ in the 2000 s reflecting the lack of confidence in the economy. Fig. 2 shows that there is a trade-off between the respective growth rates under the foreign and fiscal constraints while there was not much difference in the savings gap. Crises usually begin with a contraction of net capital inflows because of capital flight, FDI stoppage, and elevated debt service. Fig. 5 shows the savings-investment gap position whereby the gap appears in a positive situation, but at a decreased rate. This is due to the higher cut-off in the investment rate rather than improvement in the domestic resources rate. Investment fell more to $20 \%$ in 2008 from an average $22 \%$ in $2000-2007$, reflecting the lack of investors' confidence in the economy (investment draught). The capacity utilization in 1998 is less than $85 \%$, which means that the economy lost about $2 \%$ of its capacity compared to the pre-crisis period. This clearly illustrates that the foreign exchange and fiscal gaps expanded and had become worse than the 1985-86 recession due to the collapse of the commodity prices. The recovery in 1999 was, to a large extent, the result of pump-priming a depressed economy. Although a significant increase in foreign capital due to an increase in merchandise exports introduced foreign capital control policy and increased FDI inflow that helped to push foreign and fiscal gaps to move outwards as well. Total investment increased by $5 \%$ in 2002, which in turn led to an increase in capacity utilization to more than $86 \%$. There was, therefore, a significant increase in the growth rate of output from $7.3 \%$ (1998) to $4.2 \%$ (2002). In fact, we observed that both constraints became less binding since the government's internal and external policies became more effective, and the macroeconomic performance of the all sectors showed a gradual positive output growth. But how can the complicated issue that the economy creates a trade surplus on one hand, but has a higher shortage of foreign capital-higher debt on the other be explained in a situation like the post crisis period? Fig. 3 shows that the trade balance turned around to record a surplus within two months after the onset of the crisis, primarily due to a curtailment of imports. The substantial improvement to the trade balance was a result of import compression and an export boost with cheaper ringgit, i.e., the exports grew faster than imports. The current account balance also turned around to register a large surplus of US\$ 9.5, 
12.6, and 28.9 billion in 1998, 1999 and 2007, respectively (note that in 1997; there was deficit of US\$ -5.9 billion). These changes reflected the large surplus in the merchandise account. Now, the picture becomes less optimistic if we include the foreign capital outflows during the crisis, because the FDI fell from US\$ 6.8 billion in 1996 to 2.5 billion two years later. In 2007, the FDI was negative US\$ -2562 million (as shown in Fig. 6) and the portfolio investment that registered an outflow of -3.7 billion in 2005. Both the long and short term foreign capital registered increased to higher level. According to the figures, long and short term foreign capital was US\$ 40.7 and 18.8 billion, respectively in 2007. Hence, the net balance of payments shows a small surplus of US\$ 4.7 billion only in 1999 before it became negative (-974 million US dollar) in $2000^{*}$. It increased slightly to 4.4 billion in 2007. If we expand our analysis further to include foreign debt, which increased due to the fluctuation of the ringgit only by more than $50 \%$, the real problem comes to the surface. The depreciation of the ringgit had an immediate negative impact on the Malaysian external debt position, reflecting the large exchange revaluation loss as the external debt in ringgit terms increased by $48 \%$ to RM 171 billion or $64 \%$ of GNP at the end of 1998. It continue to increase reaching 197.5 billion in 2007, compared with the precrisis debt level of 99 billion or $40 \%$ of GNP at the end of 1996. Therefore, the impression was negative for one of the Malaysian foreign resources, even when the economy had recorded high trade surplus (see Fig. 3).

\section{The Effect of the Recent Global Crisis on the Resources Gap}

The Malaysia economy is severely affected by the USA global crisis. In large part, because of its dependence on advanced manufacturing exports and large spill over's from external sectors to domestic demand affecting both consumers and investor confidence which is register a negative growth rate. The performance of the economy is severely affected by this crisis due to shortages in all types of external and internal resources requirement to finance economic growth.

All the resources gaps will expand widely in next few years for the following reasons:

(1) Sharp fall in several export prices, especially for the electronic and Manufacturing goods, following a prolonged global economic recession and drop in external demand.

(2) Imports are likely to decline at a somewhat slower rate than export, followed by consumption and public investment. This in turn will lead to reduce the trade account surplus and push the ringgit to a lower level.

(3) The total burden debt is expect to increase sharply through high fluctuations of international capital market, higher volatility and risk of foreign capital inflow, increases the foreign capital outflow (flight).

(4) Net FDI and portfolio investment outflows will accelerate in the next year reflecting more intense risk rising from fluctuation of export prices, with China as a new player in Asia and the world economy.

(5) International reserves are expected to fall.

And the fiscal gap is worsen for the following reasons:

(1) The overall federal fiscal deficit will widen, since the public saving is insufficient to support government expenditure and repayment of the government foreign debt.

(2) Government revenue is expected to decline due to the low of the oil and gas prices that account for over $30 \%$ of total government revenue and decrease the tax rate by $2 \%$ as an incentive for private sector investment.

(3) Government expenditure and federal government capital spending will increase more rapidly than expected as a result of higher subsidies, civil services salaries and greater development projects.

(4) The government external debt is expected to increase to supplement the shortages in government resources and to recover the public burden debt.

The domestic gap will be less affected by the crisis, since the GDI was severely affected in the wake of the Asian financial crisis and has remained sluggish at the average $19-27 \%$ of the GDP between1997-2008, and fall further in 2009 to 14.5 percent. The domestic saving rates will continue to be at the high level averaging 38 to $42 \%$ of the GDP during 1998-2008, and it fall slightly to $35 \%$ in 2009 .

The crisis may have many other indirect effects such as domestic political uncertainty, distortion of the claim of investment, an increased risk of doing business, increased volatility of exchange rate and domestic interest rate, increased uncertainty in domestic capital market, increased unemployment rate, and fall in the labour force participation.

\section{Estimate the Effect of Recent Global Financial Crisis} 2008

Using the real data for the recent international crisis, we derive the three-gap estimates. The GDP will fall (-1.7\%) in the 2009, compared to $4.7 \%$ in year before. Net capital inflows are contract because of uncertainty, capital flight, and exchange rate volatility, term of trade, foreign direct investment stoppage, and elevated debt service. This will lead to increase capital account deficit to (-35.5) and (-22.8) bill US\$ in 2008 and 2009 respectively. FDI fall to (-7.8) bullion in 2008 and (-6.6) billion in 2009, while portfolio investment fall to $(-25.3)$ billion in 2009. Debt increase to around 70 billion in 2009 from 61.6 billion in 2007, and debt services increase sharply to 11 billion from 7.8 billion in same period. Government budget as a ratio to GDP was increase to ( - 
$7 \%)$ in 2009 from $(-3.2 \%)$ in 2007. Export growth decreasing by $9.8 \%$ percent in 2008 (199.2 billion US\$) to $-16.6 \%$ percent in 2009 (157.2 billion US\$), while import growth fall by $3.9 \%$ (148 billion US\$) to $-16.6 \%$ (117 billion US\$) in same period, ( Asian Development Bank 2010) Federal fiscal deficit is widen because public saving is insufficient to support government expenditure and repayment of the government foreign debt. Government revenue is decline significantly due to lower oil and gas and many export goods prices, and a lower the tax revenue to 106.5 billion in 2009 from 113 billion Ringgit in year before to provide incentive to the private investment. Government expenditure and federal government capital spending will increase more rapidly than expected to 206 billion in 2009 from 161 billion in 2007. The net domestic government debt is increase from 25.2 billion in 2007 to 57 billion in 2009, and net external debt expanded to 7 billion in 2009 from 474 million in 2008, to supplement the shortages in government resources, and to recover the public burden debt. The capacity utilization in 2008 is less than $83 \%$, which means that the economy lost about around 5\% of its capacity compared to the pre-crisis period. This clearly illustrates that the foreign exchange and fiscal gaps will expand sharply and had become worse than the 1997-98 recession due to the collapse of the Asian financial crisis. As shown in Fig. 2.B (the actual situation of the gaps in 2009), all three curves have shifted down and become less steeper (more elastic), which indicates that the growth rate and capacity utilization rate respond faster to any change in foreign and domestic resources. Furthermore, the small foreign capital gains from the trade surplus will be directed to alternative uses such as reserves-accumulation offset by capital outflows or to recover the burden of external debt. Thus almost, more than $90 \%$ of capital inflows from trade were used either to augment reserves or were not deployed within the country. Needless to say, the crisis is still unfolding and new disturbances cannot be ruled out. By the end of 2009, the Malaysian government faces a twin deficit situation: a fiscal deficit and current account deficit. In view of these problems, external borrowing will be sought, resulting in a significant increase in the external debt burden. In fact, there was a clear drain in Malaysian internal and external resources and this drain increased with time.

\section{Conclusions and Policy Implication}

The Malaysian economy was severely affected by recent crises -- the 1997 Asian financial crisis and the 2008 global financial crisis. In this study we conduct some simulation exercises attempt to identify the major constraints (i.e., the size of foreign capital and public sector borrowing) that need to be addressed by policymakers to push back the economy on its longterm growth path. The recovery process over the next few years will depend on the continued progress of adjustments undertaken by the global economy, but more importantly, on the responsiveness and ability of the domestic economy to adjust the production structure to the changing world demand and the opportunities that arise with it. Initiatives in diversifying the production base (especially the hightech products) will certainly increase the resilience of the economy to insulate from external shocks (World Bank, 2015).

Malaysian policymakers have come to recognize that a developing country's vulnerability in the sometimesvolatile global economy cannot be completely eliminated. Under its current circumstances, Malaysia has wisely sought to lessen its vulnerability through confidence-building measures in the banking and corporate sectors, diversification of the domestic economy with a focus on human capital formation and service development, and the implementation of more prudent macroeconomic policies. In the years to come, Malaysia can no longer rely on low wages and the accumulation of humane and physical capital. Similarly it cannot depend on export-led growth to sustain its robust levels of growth achieved in the past or to follow that model to reach its goal of becoming a fully developed economy in 2020. Growth in the future will increasingly depend upon domestic demand and knowledge lead growth strategy. For a policy perspective, our results reveal several interesting insights. First, the economy cannot depend on the external sector alone as its engine of growth. The economy must shift from growth that is solely based on exports to domestic-led growth. To achieve this desirable outcome, the private sector must resume its important role as the engine of economic growth. Second, the external debt is likely to remain as an urgent agenda during the 2000s. The surge in capital inflows will need to be carefully managed to prevent overheating in Malaysia economic and to avert an increase in vulnerability to credit and asset price cycles and macroeconomic volatility. There is a high expectation within the government for massive FDI, a factor that may contribute to raising the overall rate of capital accumulation and to alleviating external debt difficulty. The results of the relationship between foreign capital, GDP growth rate, and investment indicate that the trade gap will be more binding when policymakers attempt to push the output and investment to much higher potential levels. Thus, our findings are not in favour of setting a high growth target (say 7\%) as documented in the current five-year plan of the country. The empirical results suggest that Malaysia has to continue relying heavily on foreign capital for economic progress. Third, there is also an urgent need for the government over the next few years 
to introduce additional measures that will significantly improve the country's resources position. This can only be achieved through increasing productivity, reducing the cost of doing business, and training and acquiring new technology as more innovative and appraisal is expected to follow from the policy reforms. Several selection criteria need to be used when considering these projects; priority should be given to those projects that can generate greater use of local inputs, create high wage employment opportunities and export earnings, induce high local value-added content, save foreign exchange, have shorter gestation periods as well as enhance the overall efficiency of the economy. Finally, there is a need to upgrade its human formation and capacity building to deal with competition from lowerwage countries like China and Vietnam. This must be achieved in ways that do not increase government deficits or tax rates. Otherwise, the stable noninflationary environment for competitiveness and inflows of foreign capital will be undermined.

Notes

1. An increase in government deficits can adversely affect the competitiveness and inflows of foreign capital. A stable non-inflationary environment is required for competitiveness and inflows of foreign capital.

3. The picture becomes pessimistic if we look at capital outflow from the capital market, and to cite previous prime Minster of Malaysia Dr. Mahathir, "the stock market was wiped out of more than US\$ 100 billion in 1998 and the KLSE market capitalization fell by 76 percent".

\section{References}

1. Asia Development Bank, Asian Development Outlook 2009 (2009) Rebalancing Asia's Growth, Manila, Philippines.

2. Asia Development Bank, 2016, Key Indicators of Developing Asian and Pacific Countries, Oxford, University Press, UK.

3. Asian Development Bank, 2010, Development Indicators Reference, Oxford, University Press, UK .

4. Bacha, E. (1990) A Three-Gap Model of Foreign Transfers and The GDP Growth Rate in Developing Countries, Journal of Development Economics, 32, pp. 279-296.

5. Bacha, E. (1992) External Debt, Net Transfers and Growth in Developing Countries, World Development, 20(8), pp. 1183-1192.

6. Economic Report, (2004) Ministry of Finance, Malaysia.

7. Economic Report, (2012) Ministry of Finance, Malaysia.

8. Evan, L. \& Baharumshah, A. Z. (2006) Current Account: Mean-Reverting or Random Walk Behaviour? Japan and the World Economy, 18, pp. 90-107.
9. Frankel, J. (2005) Contractionary Currency Crashes in Developing Countries. Faculty Research Working Paper Series, WP05-017. John F. Kennedy School of Government, Harvard University.

10. Giselle, D. A. (2007) Financial Crisis in Malaysia: Did FDI Flows Contribute to Vulnerability? Journal of International Development, 19, pp. 949-962.

11. Haroon. A. \& Ardeshir. S. (2001) Trouble in Paradise? Savings and Growth in Fiji, 1970-2001, Journal of Asia Pacific Economic, 6(3), pp. 360-385.

12. Hart-Landsberg, M. (1998) The Asian crisis: Causes and Consequences, Against the Current, No.73 (March/April).

13. Iqbal, Z., James, J. \& Pyatt, G. (2000) Three-Gap Analysis of Structural Adjustment in Pakistan, Journal of Policy Modeling, 22(1), pp. 117-138.

14. Kawai, M. \& Takagi, K. (2008) A Survey of the Literature on Managing Capital Inflows, ADB Institute Discussion Paper, No 100, Asian Development Bank, Japan.

15. Rodrik, D. \& Subramanian A. (2009) Why Did Financial Globalization Disappoint, IMF Staff Papers, 56, No 1.

16. Sepehri, A, Moshiri, S. \& Doudongee, M. (2000) The Foreign Exchange Constraints to Economic Adjustment: the Case of Iran, International Review of Applied Economics, 14(2), pp. 235-251.

17. Taylor, L. (1993) The Rocky Road to Reform (Ed). MIT Press, London.

18. Taylor, L. (1994) Gap models, Journal of Development Economics, 45, pp. 17-34.

19. Thanoon, A. M. \& Baharumshah, A. Z. (2003) Road to Recovery in Malaysia: A Three-Gap Model Analysis, Journal of Policy Modeling, 25(8), pp. 857-861.

20. Thanoon, A. M., Baharumshah, A. Z. \& AbdulRahman, A. (2006) Malaysia: From Economic Recovery to Sustained Economic Growth, Journal of Post Keynesian Economics, 28(2), pp. 295-315.

21. Whitt, J. (1999) The Role of External Shocks in The Asian Financial Crisis, Economic Review (Federal Reserve Bank of Atlanta) Second Quarter, pp. 18-31.

22. World Bank, Global Development Finance 2009 (2009) Charting a Global Recovery, Washington D.C., New York.

\section{Footnote}

* The picture becomes pessimistic if we look at capital outflow from the capital market, and to cite previous prime Minster of Malaysia Dr. Mahathir, "the stock market was wiped out of more than US\$ 100 billion in 1998 and the KLSE market capitalization fell by 76 percent". 
Table (1) : Equations of The Three-Gap Model

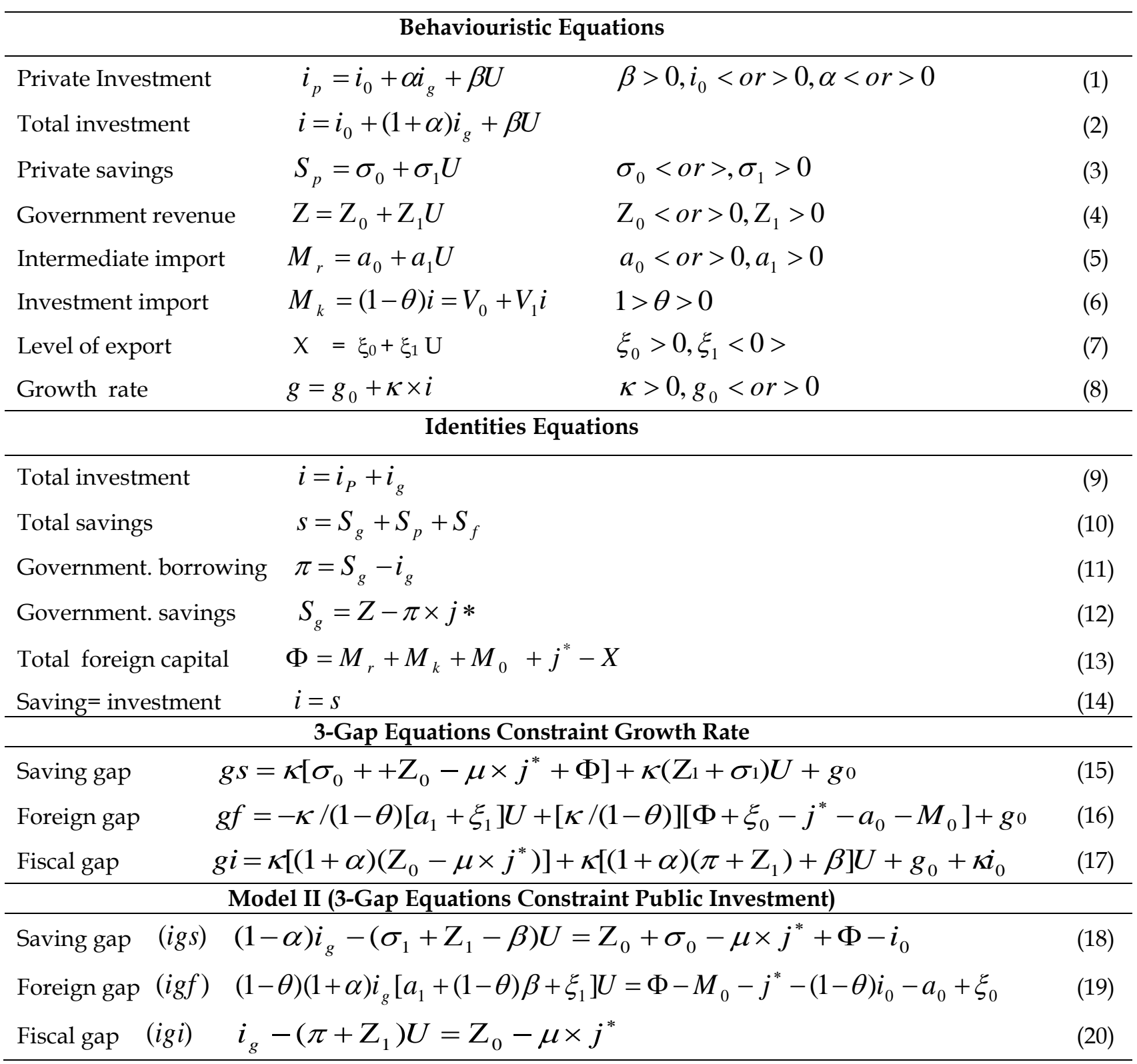

The result of estimation are available in " Thanoon, A. M., Baharumshah, A. Z. \& AbdulRahman, A. (2006) Malaysia: from economic recovery to sustained economic growth, Journal of Post Keynesian Economics, 28(2), pp. 305-315. 
Table (2) : Three-gap results

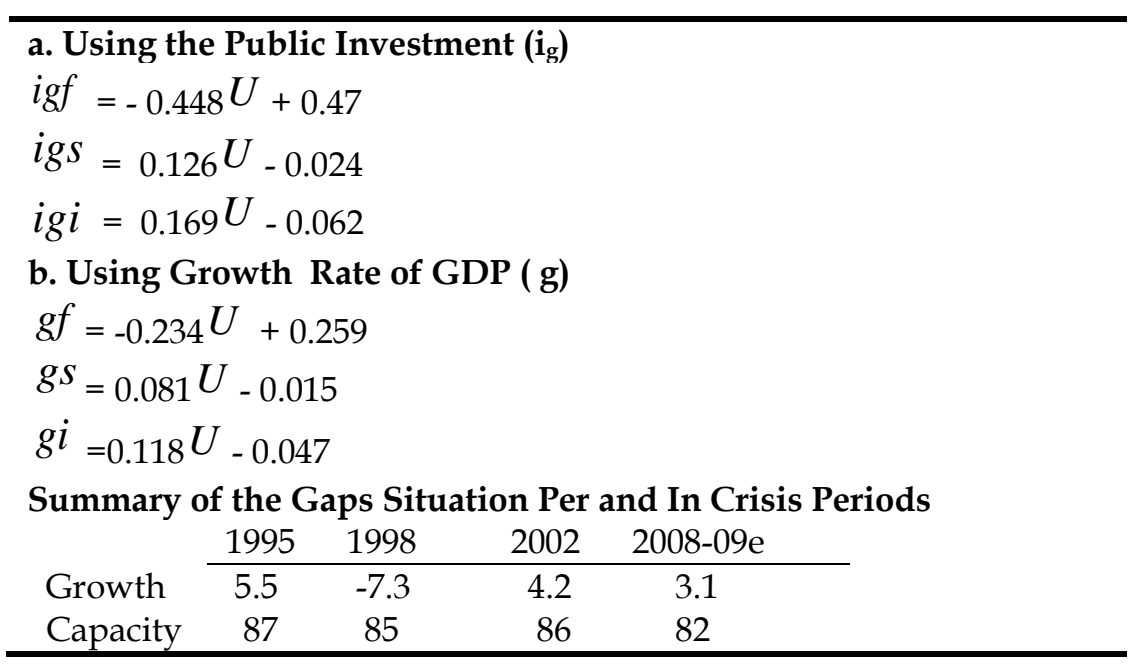

Figure (1) : Foreign exchange, saving and fiscal gaps pre-crisis

Growth rate (\%)

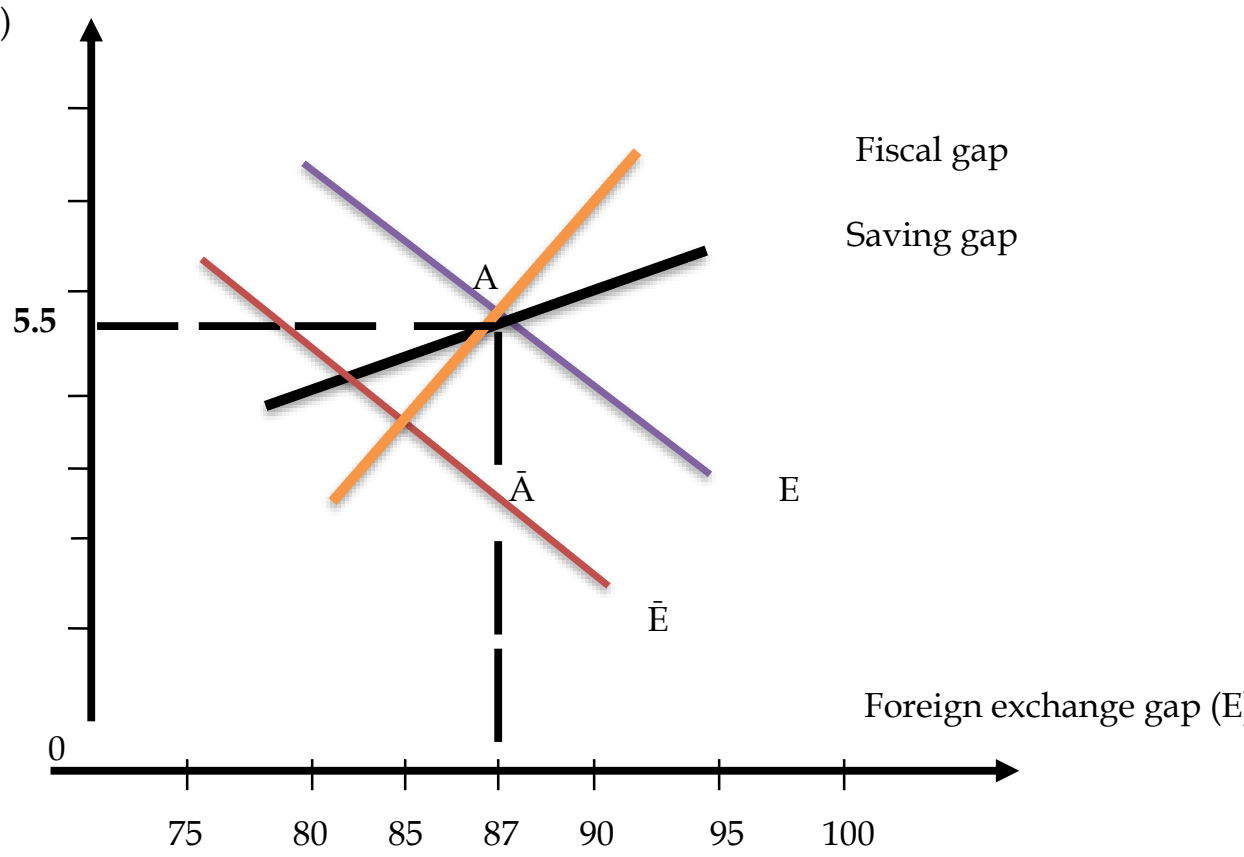

Capacity Utilization rate (\%) 
Figure (2.A) : Foreign exchange, saving and fiscal in-crisis

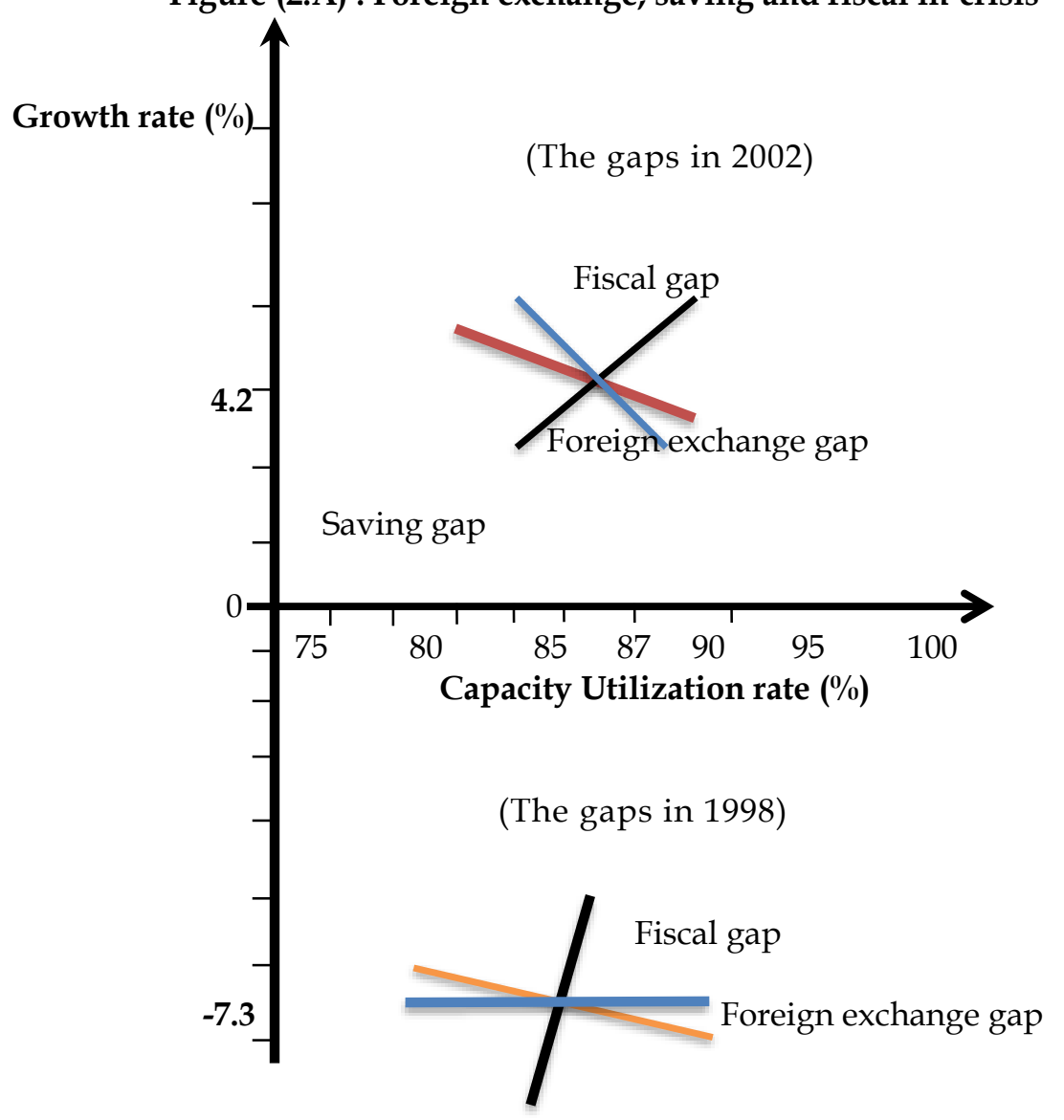

Saving gap

Figure (2.B) : Actual foreign exchange, saving and fiscal in 2009

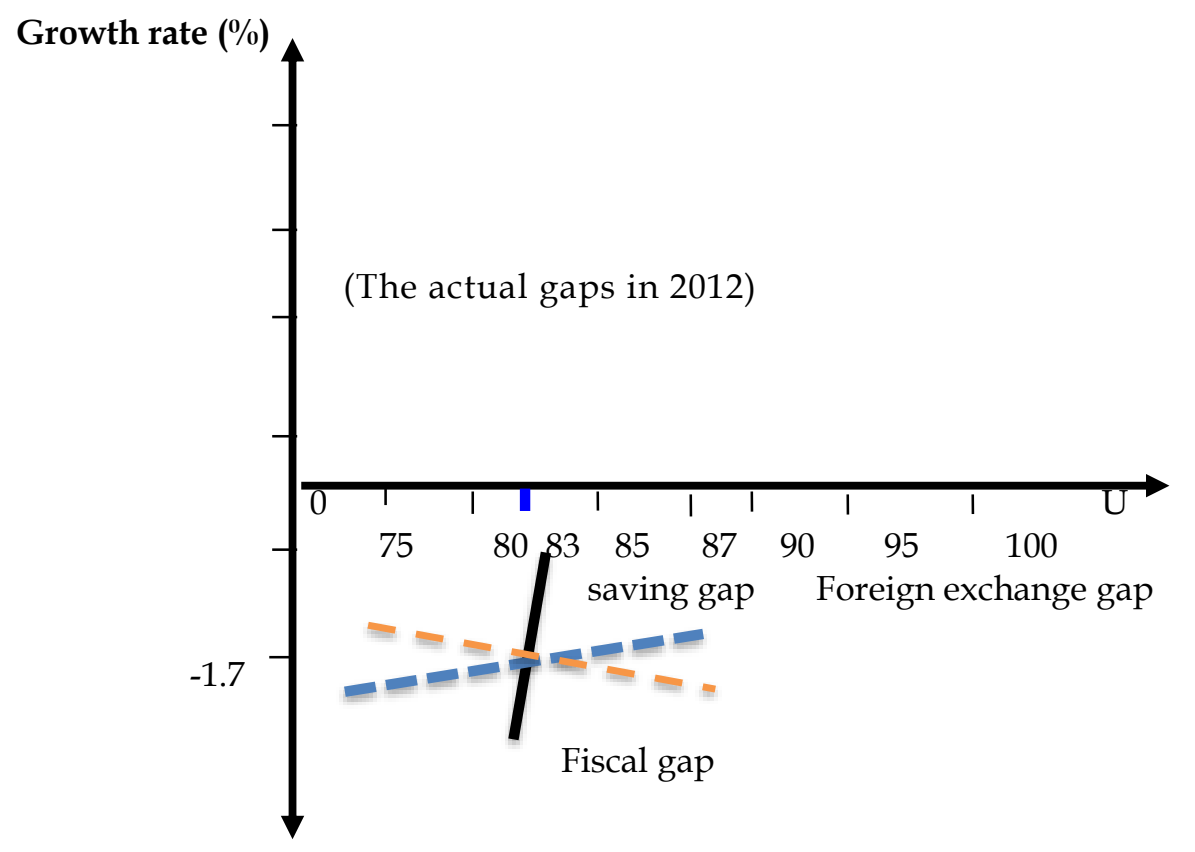


Figure (3) : Increase in trade surplus and total debt burden

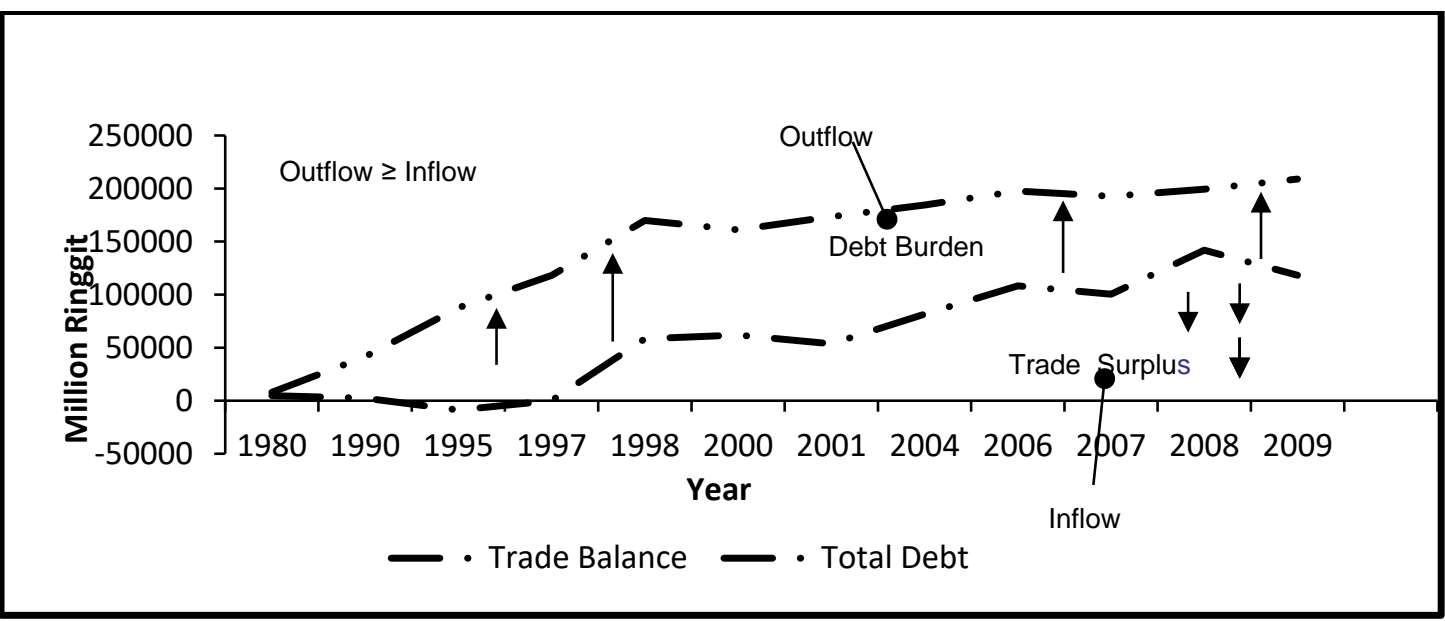

Figure (4) : Fiscal gap as a ratio to GDP

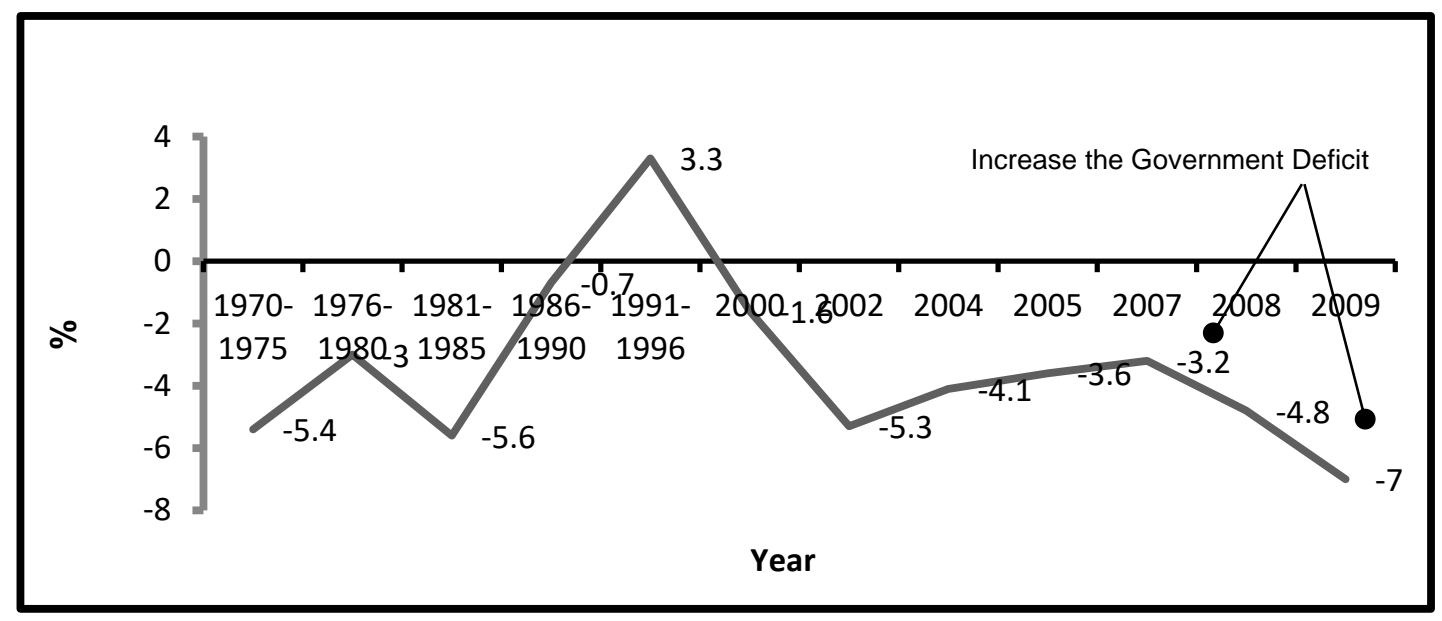

Figure (5) : Saving-investment gap

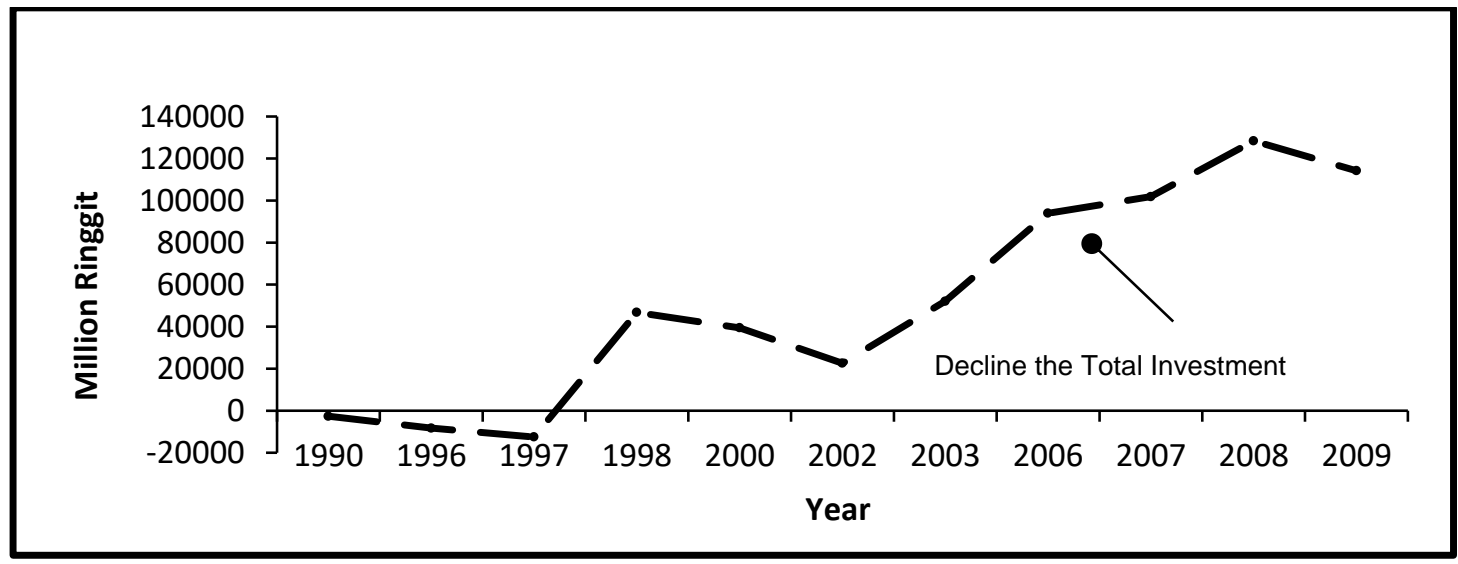


Figure( 6) : Foreign direct investment inflow

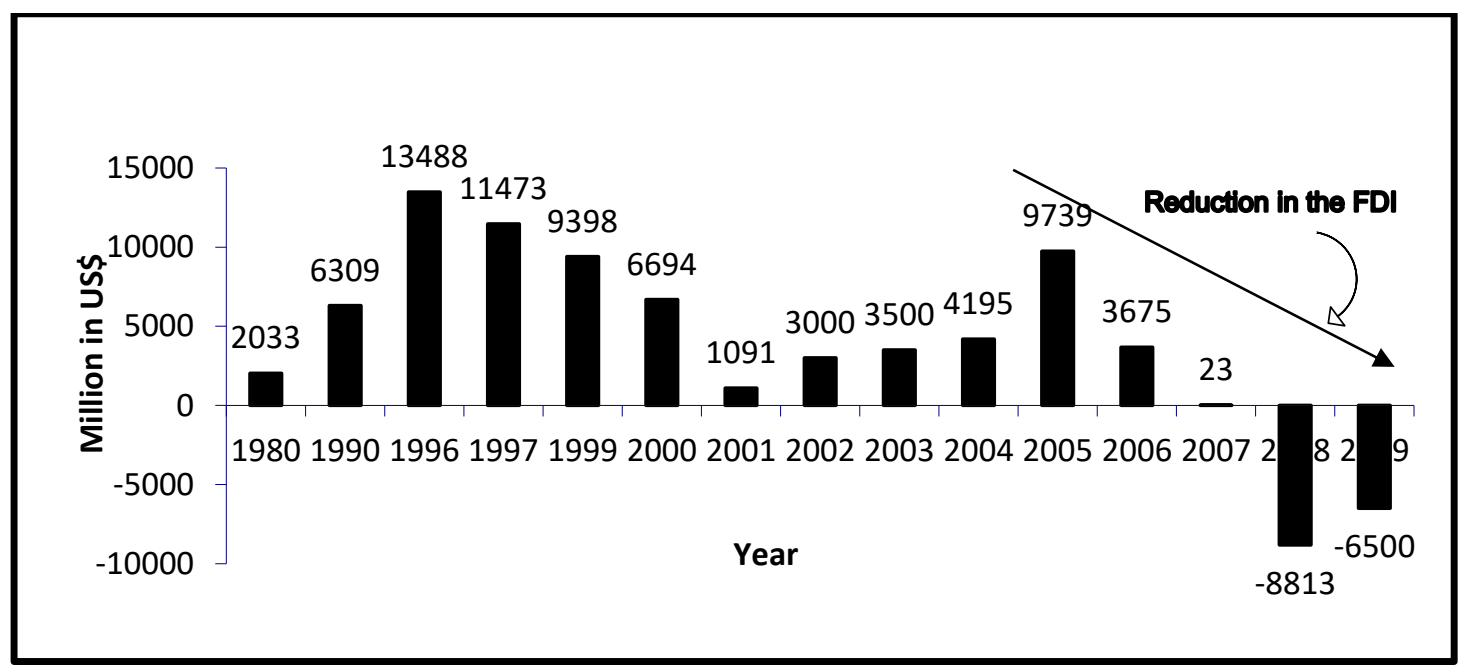

